体力科学 (2009) 58,12

【教育講演 $5:$ : どもの体力低下から見えてくるもの】

子どもの体力低下から見えてくるもの

中 村 和 彦

(山梨大学教育人間科学部)

I. 子どものからだの問題と体力低下

体力・運動能力の低下とともに, 今日の子どもの からだにはさまざまな問題が生じてきています . 例 えば,つまずいて転んだりして顔面や手首のけがを する子どもが増加しています . 幼児期からのさまざ まな運動経験の不足から，からだをコントロールす る能力が身についていないといえます．また運動不 足から肥満傾向にある子どもが増大しています．結 果として, 高血圧症・糖尿病といった生活習慣病に 罹患している子どもや光の予備軍となっている子ど もも少なくありません．このように体力テストに現 れる数值の低下は, 今日の子どものからだの問題, すなわちけがや病気と密接な関係を持っているとい えます．

\section{II. 子どもの体力低下の直接的な原因}

体力低下の直接的な原因として，「基本的な動作 の未習得」と「運動量の減少」をあげることができ ます．

今こども達には，基本的な動作が身についていま せん.このような基本的な動作は, 2 - 3 歳の幼児 期の未熟な段階からさまざまな身体活動の学習や経 験を通して，およ光11・12歳の少年期の頃までにお となの動作に近い成熟したレベルにまで発達し，光 の後, スポーツや生活の中に現れるより専門的な動 作を獲得していくといわれています. 基本的な動作 の習得には，さまざまな動作のレパートリーを増大 し, 光のバリエーションを拡大させていく「動作の

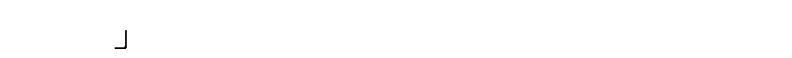

を上手にし，より合理的・合目的的な動作に变容さ せていく「動作の洗練化」という2 つの方向性があ ります．今日のこども達は，さまざまな基本的動作 を経験できる身体活動を伴う遊びの消失や，単一ス ポーツのみの実施によって, 動作の多樣化と洗練化 ともに未熟な段階にとどまっています．特に，今日 の小学校 3 年生 ( 8 歳) $\cdot 4$ 年生 (9 歳) の基本的 な動作の発達段階は，23年前の年長児 ( 5 歳) の段 階にとどまっていることが明らかになっています．

また，運動量（歩数）をみると，今日の小学生の 1 日の平均歩数は 13,000 歩と, 昭和 40 年代の小学生 の半分以下にまで咸少しています。

\section{III. 体力・運動能力つくりのための取り組み}

子ども達の体力・運動能力を向上させるための取 り組みとして, 以下の 3 つの観点が重要と考えられ ます。

(1)児童生徒の基本的な動作の習得と, 運動量の增 大を目指した身体活動の充実

(2)食事・睡眠を中心としたライフスタイル( 生活 習慣）の改善

(3)子どもの体力・運動能力つくりに対するおとな

（教師・保護者等）の意識の向上

これらに取り組むためには, 学校・家庭・地域社 会が連携を图りながら日常生活全体をトータルに捉 えた実践を行っていくことが必要です．さらに「幼 稚園や保育園・小学校・中学校・高等学校」という 子どもの体力・運動能力つくりを緃断的に保障して いく縦の連携も重要な課題であると考えます． 